
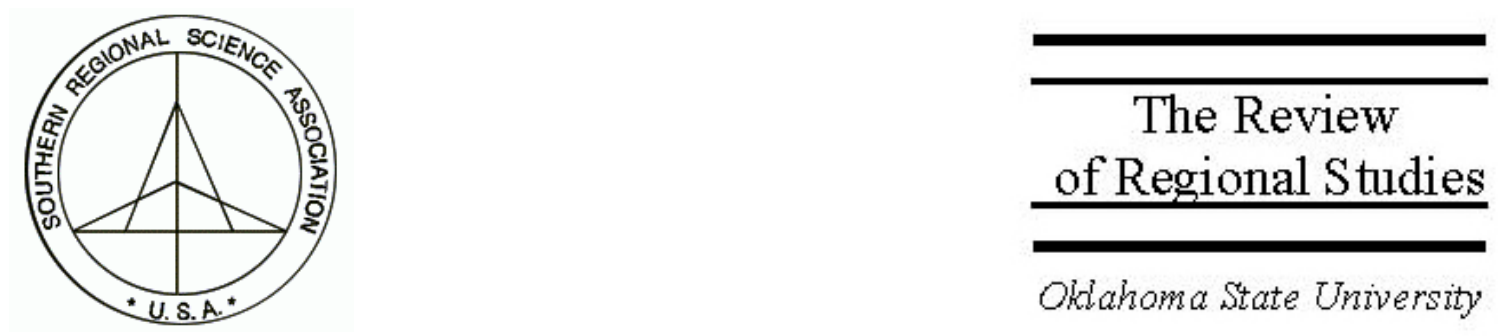

\title{
Do We Know Economic Development When We See It?
}

\author{
Mark D. Partridge \\ Department of Economics, 386 Stewart Hall, St. Cloud State University \\ St. Cloud, MN 56301-4498, email: mpartridge@stcloudstate.edu \\ Dan S. Rickman \\ Department of Economics, 338 College of Business, Oklahoma State University \\ Stillwater,OK 74078,email: rdan@okstate.edu
}

\begin{abstract}
Considerable ambiguity exists regarding the assessment of regional economic development. Alternative measures often produce conflicting conclusions. Even if economic development progress is defined as improvement in economic welfare, it is not directly measurable. Therefore, this paper develops a theoretical framework that explores the potential linkages between regional utility and commonly used economic measures. State trends in these measures are then examined for the 1990s and related to the theoretical framework. The exercise reveals that no single measure should be preferred in assessing economic development, although it is possible to separate strong performers from weak performers.
\end{abstract}

\footnotetext{
${ }^{*}$ The authors thank Alan Schlottmann for suggesting the topic of this paper.
} 


\section{INTRODUCTION}

In assessing a region's economic development or performance, a politician or social commentator can always find one indicator that is extremely favorable or extremely unfavorable. For example, Connecticut had the highest per capita income in 1999, while it also had the slowest job growth in the 1990s. Public discourse regarding economic development often becomes muddled with claims and counterclaims based on competing statistics that are all alleged to measure economic development. ${ }^{1}$ Given the plethora of potential concepts and measures, the question arises as to whether we know economic development when we see it.

In a review of the literature on the politics of economic development, Wolman and Spitzley (1996) observe that there is considerable disagreement as to what constitutes economic development. The U.S. Economic Development Administration (EDA) states that economic development is "fundamentally about enhancing the factors of productive capacity-land, labor, capital, and technology..." (www.doc.gov/eda/). At its twenty-ninth Annual Conference, the Southern Growth Policies Board unveiled a 10-year strategic plan to transform the southern economy (www.southern.org). A central theme of the plan is the enhancement of the quality of life, including economic well being. This theme is echoed in the academic literature by Courant (1994), who argues persuasively that economic development should be thought of as improvement in economic welfare. Yet direct measurement of economic welfare is not possible, which raises the issue of which statistics provide evidence of welfare improvement.

Therefore, assuming that economic development should equate with increases in economic welfare, this paper develops a theoretical framework that explores potential links between regional utility creation and commonly used measures of economic development. State trends in these measures are then examined for the 1990s and are related to the results of the theoretical framework. The exercise reveals that no single measure should be preferred in assessing economic development. Combinations of measures are typically required to assess economic development progress, with the particular combination dependent upon the characteristics of the region.

\section{THEORETICAL FRAMEWORK}

This section develops a framework for exploring potential theoretical linkages between various regional economic measures and the likelihood of utility creation. The emphasis is placed upon highlighting the probable labor demand and labor supply linkages to economic welfare once both direct and indirect channels of influence are revealed. Hypothetical economic development policies are used to derive both the possible short- and long-run relationships among various economic development measures and regional utility. The framework developed below follows in the spirit of the static general equilibrium approach developed by Roback (1982) and extended into a growth context by Mathur and Stein (1993). In the interest of brevity, we refrain from formal demonstrations of equilibrium, stability, and comparative static exercises.

\footnotetext{
${ }^{1}$ Examples for New York City are highlighted in Beauregard (1999).
} 


\subsection{Basic Conceptual Model}

Following Rosen (1979) and subsequent literature (e.g., Greenwood and Hunt 1989; Mueser and Graves 1995; Brown, Hayes, and Taylor 2003), residents of a region are assumed to derive utility from both pecuniary and nonpecuniary goods. Ignoring issues of savings and intertemporal consumption, we assume that residents in region $k$ derive utility $(U)$ from expected consumption of private goods $\left(C_{p}\right)$, consumption of local public goods $(Z)$, and location specific amenities $(A)$ :

(1) $U^{k}=U^{k}\left(p r \cdot C_{p}, Z, A\right)$,

where following in the Harris and Todaro (1970) tradition, $p r$ represents the probability of obtaining the typical private consumption bundle in the region through employment earnings. A lower unemployment rate and a higher labor force participation rate increase the probability of private good consumption. The public good is assumed nonexcludable but potentially rival in consumption. $^{2}$

Individuals receive a wage rate $(W)$ as compensation for a unit of their labor services and reside in the region in which they work. The regional pattern of land ownership is independent of the location of labor. ${ }^{3}$ In typical short-run Keynesian fashion, $W$ is a nonlinear positive function of the ratio of labor demand to labor supply, with smaller responses occurring when the economy is below full employment. Yet in the long-run, wages return to their equilibrium as determined by labor productivity and worker location preferences. Each individual's contribution to financing the public good is given by the tax rate $(t)$, with private consumption given by disposable income $((1-t) \cdot W)$. We assume that except housing services, private goods are purchased in a national market at a uniform price. Thus, regional production of the private good does not directly depend upon the regional distribution of households and income. The price of housing services increases with the cost of land $(R)$, which depends positively on population $(N)$. As $N$ goes from zero towards infinity, local public goods first experience economies of scale and then diseconomies of scale (e.g., congestion effects). For a fixed perperson provision of public goods, economies of scale in public good provision implies that greater population leads to a lower $t$, increasing disposable income and consumption of the private good.

Amenities are endogenous, depending on both a fixed level of natural amenity stocks $(S)$ and population. Starting at a sufficiently low level, an increase in population can increase amenity levels, such as increasing the availability of cultural attractions. Beyond some level of

\footnotetext{
${ }^{2}$ Gyourko and Tracy (1989) and Dalenberg and Partridge (1997) respectively show that local fiscal conditions and public infrastructure are significant determinants of the variance of local wages, which indicates the importance of governmental policies in residential choice.

${ }^{3}$ The assumption of land ownership being independent of the location of labor is made for simplicity. This assumption along with the assumption of the nationally traded export good allows us to avoid the complex issues that could arise when changes in land prices affect the demand for regionally produced goods by the initial owners of the land. Since changes in land and residential housing prices generally move in the same direction as overall regional production, this simplifying assumption comes at little cost.
} 
population, however, amenity values can decrease because of environmental degradation such as reduced air quality and/or the loss of open spaces, as well as increased congestion. ${ }^{4}$

Firms minimize costs $(C)$ in their regional location. Costs are determined by the wage rate, the cost of land, and an exogenous component $(X): C^{k}(W, R, X)$. Examples of exogenous costs include economic development policies in the form of tax breaks, or subsidies such as free land. Yet policies related to economic development can be more subtle, or indirect, and can include the enhancement of human capital and public capital or improving the area's environment and livability. For example, Brown, Hayes, and Taylor (2003) develop a model with a wide range of government policies. For now, we assume that amenities $(A)$ are nonproductive.

We assume that the economic development goal of a social planner should be to maximize the utility of the representative household. This contrasts with simply maximizing total utility, which includes the utility of residents ex post to the implementation of the development policies. $^{5}$ Constrained maximization of (1) for the typical household yields the following indirect utility function:

(2) $V^{k}(W, R, N, S, p r, t)$.

Utility is positively related to the wage rate, as it provides for increased consumption of private and public goods. A higher price of land reduces the income available for other purchases, lowering utility. Utility also is positively related to the exogenous stock of amenities. Reflecting the assumptions of an optimal population size in public good and amenity provision, utility is assumed to be a concave function of population with a positive first derivative at zero. ${ }^{6}$ Finally, a higher probability of employment increases utility, while a higher tax rate lowers utility (for a fixed level of per-capita public good provision).

Equalization of household utility and costs across regions characterizes long-run equilibrium. Each region is assumed sufficiently small such that any movement of people or firms into region $k$ does not impact the utility or production cost of the rest-of-the-world $(R O W)$. However, adjustments to equilibrium are not assumed instantaneous. Therefore, in equilibrium, utility in region $k$ is fixed at a benchmark level: $V^{k}=V^{R O W}$. Yet for a given period of time, utility differentials may exist. For example, monetary and psychic costs of household relocation likely prevent instantaneous equalization of regional utility levels (Partridge and Rickman 1997a). Instead of instantaneous adjustment, we assume a partial-adjustment mechanism in which net migration $(M)$ into region $k$ partially responds to the current-period utility differential (e.g., Treyz et al. 1993):

(3) $M^{k}=\alpha_{M}^{k}\left(V^{k}-V^{R O W}\right)$,

\footnotetext{
${ }^{4}$ Hansen (2001) notes that net-domestic migration during 1990-1995 was positive for metropolitan areas with populations of 1.0-2.5 million (and smaller), while only three of the 18 metropolitan areas with more than 2.5 million had positive net domestic in-migration. He views this as evidence of urban disamenities associated with size.

${ }^{5}$ Maximization of the typical household's utility is akin to maximizing utility of the original residents (e.g., Morgan, Mutti, and Rickman 1996).

${ }^{6}$ Herzog and Schlottmann (1993) found a nonlinear relationship between urban scale and amenities.
} 
where $\alpha_{M}$ represents the speed of migration adjustment, which can vary depending on the structural and economic characteristics of the region. These characteristics include pecuniary and nonpecuniary migration costs as well as information constraints.

Long-run equilibrium also dictates equalization of production costs across regions, which are normalized to equal unity: $C^{k}=1$. Lower costs in region $k$ induce movement of firms $(F)$ into the region, in which a partial-adjustment process also is specified:

(4) $F^{k}=\alpha_{F}^{k}\left(1-C^{k}\right)$,

where $\alpha_{F}$ represents the firm regional relocation adjustment speed, which also can vary across regions.

\subsection{Regional Growth and Utility}

As a simple exercise to explore the potential linkages between growth and utility, we assume a hypothetical exogenous decrease in unit costs $(X)$ that results from the implementation of some economic development policy. For simplicity, it also is assumed that the policy does not incur an opportunity cost elsewhere in the economy, although in practice the decrease in $X$ can reflect the net impact of offsetting government policies (e.g., a tax increase to acquire land). Growth in regional aggregates such as employment, population, wage rates, and per capita income will be examined under various scenarios in both the short and long run.

Equation 4 indicates that the initial effect of the cost decrease is a net movement of firms into region $k$ from the $R O W$, which increases labor demand relative to existing labor supply. This increases the wage rate, increasing utility in region $k$ above that of the $R O W$. Along with increased hiring from existing firms, migration also positively responds (by equation 3 ), partially mitigating the wage increase in the initial period. Increased population causes housing prices to increase, reducing the real wage, which has an offsetting impact on utility. The increases in land prices and nominal wage rate also offset some of the exogenous reduction in costs, limiting the net gain in firms to region $k$.

Short-run utility gains are greater if the economy begins below full employment such that the employment probability $p r$ increases. Wage increases also are muted if the economy starts below full employment, which provides less of a cost offset to the reduction in $X$ and greater net movement of firms into region $k$. Likewise, if initial population density is sufficiently low, economies of scale in public good provision results, lowering $t$, increasing private consumption $C_{p}$ and regional utility. A sufficiently low initial population density also leads to an amenity increase as population grows, further widening the utility differentials between region $k$ and the $R O W$, inducing additional migration.

As migration continues in subsequent periods, real wages and $p r$ continue to fall towards their initial levels, while public-good scale economies and additions to amenity levels diminish or even turn negative. If $\alpha_{M}$ is sufficiently small, utility differentials created by the economic development policy exist for a considerable period of time. Likewise, firms move into region $k$ 
until costs are once again equalized, with a small value of $\alpha_{F}$, producing a lengthy adjustment process. ${ }^{7}$

Positive growth for many years in most regional aggregates would be expected under this favorable scenario. The number of firms, employment, and total personal income all increase. Reduced unemployment and increased labor force participation also limit the number of new jobs filled by in-migrants, which causes employment growth to exceed population growth. Yet increased real wage rates, reduced tax rates, and increased amenity levels induce additional migration and population growth. Real per capita income rises with the increases in real wage rates and the employment-population ratio.

Long-run equilibrium dictates utility equalization but not necessarily equalization of nominal or real wage rates. Acting as compensating differentials, increased amenities and lower tax rates tend to reduce the real wage rate in the long run. Likewise, lower unemployment rates and higher labor force-population rates in equilibrium tend to reduce the real wage in the long run, as residents require less compensation for the lower risk of unemployment. ${ }^{8}$ The equilibrium values of unemployment and wage rates, however, have been shown to depend upon the wagesetting process (McGregor, Swales, and Yin 1995). Equalization of employer costs implies that the combined cost effect of the change in the nominal wage rate and in land prices offsets the cost advantage obtained through the economic development policy. With land prices increasing, any positive nominal wage change is limited. Thus, although there is a long-run increase in employment and population, the change in real per capita income is ambiguous, depending in part upon how much real wage rates compensate for the other factors.

Utility gains are considerably smaller in the short run if the economy instead operates at full employment, has exhausted scale economies in public-good provision, and population growth reduces the amenity value of the region. Although the question of optimal size has been the subject of numerous studies (e.g., Moomaw 1981), this less favorable scenario seems more likely to apply to very large metropolitan areas. Under this scenario, there are offsetting effects on inmigration. Starting at full employment implies that new jobs must be filled by in-migrants. Yet smaller utility differentials from the congestion of public goods, an increase in the tax rate, and environmental degradation induce less initial in-migration. In addition, when starting at full employment, employment gains produce a greater nominal wage rate increase than otherwise would be the case. This process offsets the exogenous unit-cost reduction and limits the net gain of new firms. Thus, employment and population growth are greatly limited.

In the long run, real wage rates likely increase to compensate residents for the reduction in amenity values. Nominal wage rates increase even more to offset the increases in tax rates and land prices. Yet to remain competitive with the $R O W$, the increases are limited by the magnitude of the unit-cost reduction provided by the economic development policy. Real wage rates and

\footnotetext{
${ }^{7}$ Treyz et al. (1993) suggest a lengthy migration adjustment process in the United States, while Bartik (1993) argues that labor markets adjust rather slowly. The slow economic convergence of U.S. states found by Barro and Sala-iMartin (1992) also suggests a lengthy adjustment process towards long-run equilibrium. However, Blanchard and Katz (1992) argue that labor markets return to equilibrium rather quickly.

${ }^{8}$ Marston (1985) and Partridge and Rickman (1997a; 1997b) provide empirical support for higher wage rates serving as compensation for higher unemployment, although Blanchflower and Oswald (1994) provide a dissenting view.
} 
per capita income increase in the long run but only to offset the reduction in amenity levels in restoring interregional equilibrium.

Other permutations of outcomes can be obtained by uncoupling the full employment and optimal size assumptions. For example, in an economy that is at or beyond its optimal size but operating below full employment, the increase in labor demand causes employment to grow much faster than population. Rather than by new migrants, employment growth is fueled primarily by lower unemployment and greater labor force participation, both contributing to increases in per capita income. In the long run, the increased probability of employment lowers the required compensating wage differential, though in the short run increased $p r$ causes wages to increase.

In contrast, an economy that is below its optimal size but at full employment likely experiences population growth in excess of employment growth. Migration primarily supplies the increase in employment. Per capita income likely declines as lower wage rates result from an increase in amenity attractiveness and from the absence of gains in the employment rate.

Instead of directly targeting firms, development policies also may target households, directly stimulating labor supply. These policies can be multiple-fold and can include investments in human capital and environmental enhancement. For example, efforts to revitalize central cities are not only intended to increase visitation, they also are intended to improve the community's livability. Increased amenity attractiveness then causes household utility in region $k$ to rise above that of other regions. The utility differential induces in-migration of labor, which in turn reduces the wage rate and increases employment. Additional short-run gains in population and employment occur if the region begins below its optimal size. Increased amenity attractiveness acts to reduce the real wage rate in the long run. A long-run mitigating factor to the wage reduction is the likely increase in unemployment and reduction in the employment-population rate, which requires greater compensation to maintain expected utility. Per capita income declines because of both the reduction in the wage rate and likely decrease in the employmentpopulation rate.

\subsection{Potential Extensions of the Model}

The assumption in the model that amenities do not affect productivity produces a negative relationship between amenities and the real wage rate. If amenities are also assumed to affect productivity, the relationship between amenities and the real wage rate becomes ambiguous. Higher producer amenity levels lower cost through increasing productivity, which allows firms to be competitive while paying higher wages and rental rates. Examples of such a policy would be the construction of an airport or highway that enhances firm productivity. An area high in both household and producer amenities will possess higher land prices, all else equal, but the combined effect on the nominal wage rate is ambiguous (Beeson and Eberts 1989).

Like household amenities, producer amenities also have been thought to vary with size of the region. For cities, increased size is believed to be associated with firms being located in close proximity. And close proximity can produce positive pecuniary and non-pecuniary spillovers between them, which are commonly known as urbanization externalities (e.g., Jacobs 1969; 
Glaeser et al. 1992). These externalities may be caused by more specialized input markets (e.g., a wider range of producer services), larger labor pools, or from enhanced cross-industry information spillovers that increase productivity. Closely associated are localization externalities, where concentrations of a particular industry in a geographic area enhance knowledge transfers within that industry, as well as improving the availability of specialized labor for that industry. These externalities can be static in that they affect the level of economic development or dynamic (or endogenous) in that growth rates are permanently affected. For dynamic externalities, the urbanization-type externalities are often referred to as diversity externalities, while the dynamic version of localization externalities are often referred to as Marshall-Arrow-Romer externalities (Romer 1986). For example, in a study of U.S. states for 1989-1998, Riddel and Schwer (2003) found that the availability of a "pool" of high-tech labor was associated with technological innovation.

Congestion of highways and other infrastructure may limit productivity benefits of size. Thus, if we measure size by population, productivity is likely to increase over some range of population and turn negative at some population level. ${ }^{9}$ The optimum size for productivity need not correspond to that for household amenities. For example, Glaeser, Sheinkman, and Shleifer (1995) note the possibility that income growth may result from a combination of increased productivity and decreased quality of life that may accompany city size. This illustrates the difficulty in directly interpreting wage changes as evidence in favor, or against, increased regional economic welfare.

With homogeneous labor, the model also does not address equity effects of economic development. Following Roback (1988), labor could be separated into high- $(H)$ and low-skilled $(L)$ categories. If the labor categories possess differing pre-existing labor market conditions and varying responses to exogenous shocks, more varied outcomes of economic development policy are possible. For example, because of proportionately greater reductions in unemployment and increases in labor force participation, Bartik $(1996,2001)$ argues that low-skilled labor benefits more from strong job growth than high-skilled labor. Likewise, Bound, and Holzer (2000) found low-skilled labor market outcomes more dependent on demand conditions, which they attributed to a lower willingness to migrate among low-skilled workers. On the contrary, Levernier, Partridge, and Rickman (2000) found little evidence that economic growth was associated with lower poverty in the $1980 \mathrm{~s}$. One implication is that economic growth may have a stronger effect on low-income workers when labor-market conditions are particularly robust as employers have fewer alternatives in their hiring decision (Freeman 2001). Increased relative growth of lowskilled jobs may skew the average wage rate downwards, however, while low-skilled per capita income and welfare increases because of higher employment rates.

For high-skilled workers, in addition to the usual negative supply-side effect, increased inmigration also may have a positive effect on wages through enhanced productivity resulting from knowledge externalities. Empirical support can be found in Rauch (1993), who found that highskilled wages were positively related to the area's concentration of high-skilled workers. In addition, if amenities are normal goods, skilled workers will have a stronger preference for them (Roback 1988; Glaeser et al. 2000). Deterioration in amenities then requires greater

\footnotetext{
${ }^{9}$ Moomaw (1983) discusses the usefulness of population as an indicator of business agglomeration economies.
} 
compensation for high-skilled labor than low-skilled labor. Thus, changes in wage rates for high-skilled labor are even less straightforward to interpret in terms of their underlying causes.

\section{MEASURING ECONOMIC DEVELOPMENT IN PRACTICE}

Even though relatively simple, our basic model shows that the measurement of economic development is a complex function of employment growth, net migration, and income. The tradeoff between amenities and income in determining overall well being and issues of social equity and fairness further complicate the measurement of total social welfare. Nonetheless, to examine this issue in practice, several commonly used measures of economic development are presented in Tables 1 and 2 for the 48 contiguous U.S. states. The selected measures are from a four- to ten-year period to capture medium- and long-term trends.

One possible direct way to assess whether people view an area as more attractive relative to other areas is to examine whether more people are moving into the area than are moving out (Douglas 1997; Hansen 2001). Yet pecuniary and nonpecuniary costs such as "sense of place" as well as information limitations may impede migration such that it does not reflect actual utility differentials. In particular, these migration constraints are thought to be particularly relevant for low-income households (Bound and Holzer 2000), suggesting that net labormigration may be more likely to reflect utility differentials for high-skilled workers. A further complication is that overall net-migration includes nonlabor-force participants such as retirees whose migration patterns are not captured by the models in the last section. For example, an influx of retirees into an area with a warm climate does not represent a labor-supply shock but rather is a labor demand shock that boosts employment and wages.

Nevertheless, to explore the patterns of migration, Columns (1)-(3) of Table 1 show rankings for three measures of 1990-1999 net migration, each calculated as a share of April 1990 population. Column (1) shows the ranking of net domestic migration's role in determining population growth, while column (2) reports the ranking for net foreign immigration's contribution to population growth. Column (3) reports the total net migration (domestic + foreign) ranking. ${ }^{10}$

From Table 1, we see that except California, a state's net domestic migration ranking is very close to its overall ranking. The foreign and domestic net migration also are generally not positively correlated and, more importantly, are negatively correlated in high-immigration states of California, New York, New Jersey, and Illinois (see Frey 1995). ${ }^{11}$ However, given that foreign immigrants concentrate in certain gateway communities that depend more on historical precedent than on public policy (e.g., California happens to border Mexico), they likely do not reflect utility differentials across states. Therefore, we interpret net domestic migration as better reflecting the well being of the original residents in the state.

\footnotetext{
${ }^{10}$ These numbers do not reflect the 2000 Census because net migration figures were not available when this was written. So, as discovered in the 2000 Census, these figures likely understate foreign immigration (Porter 2001), although it is likely that this only affects the scale of immigration, not the relative rank. The total migration ranking also ignores federal movements into and out of the country, which is a relatively small component of overall population movement.

${ }_{11}$ The Spearman rank correlation coefficient $r_{s}$ between state domestic and international migration rates among all 48 states is -.002 .
} 
TABLE 1

Ranking of State Migration and Labor Market Performances ${ }^{\mathrm{a}}$

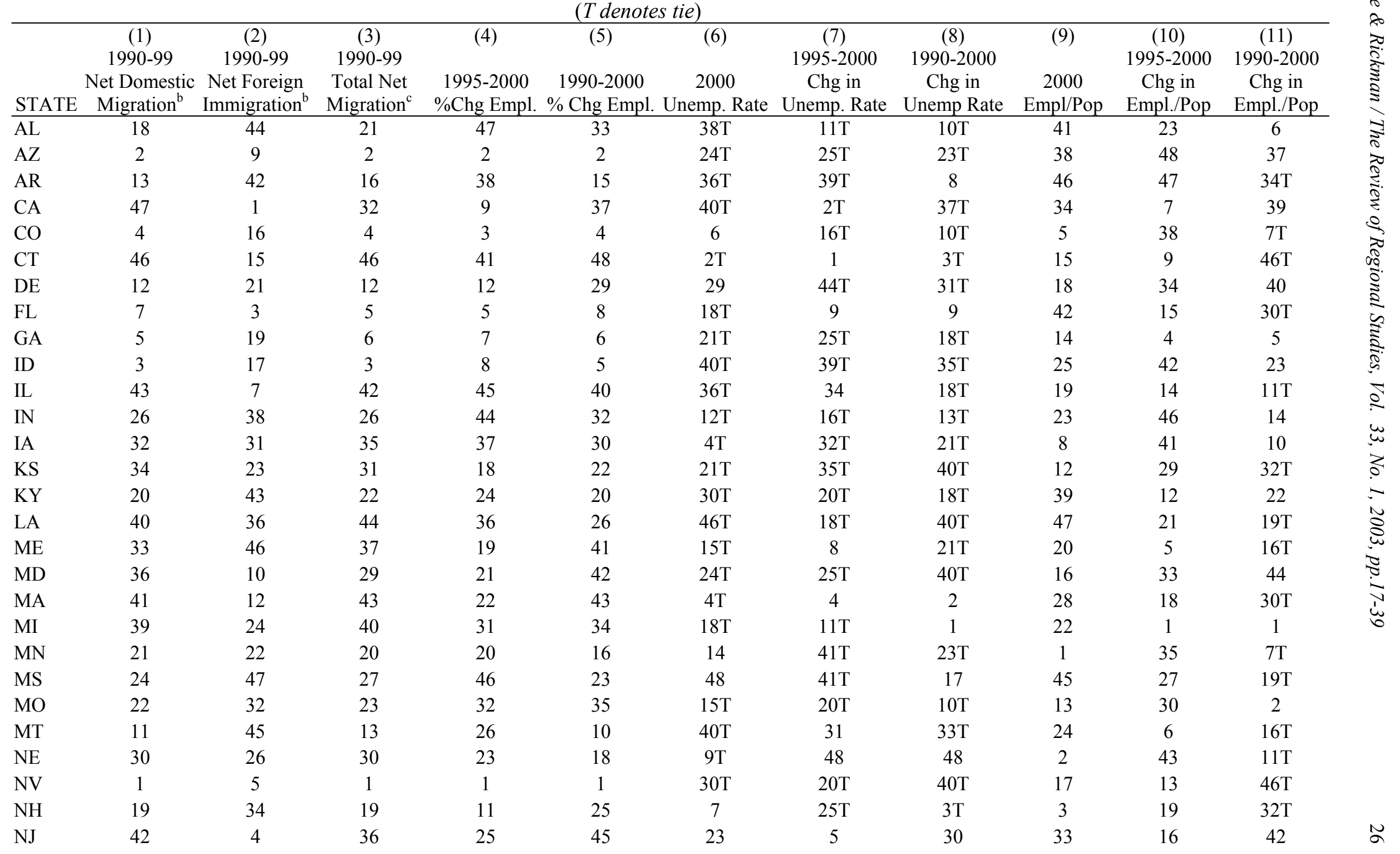




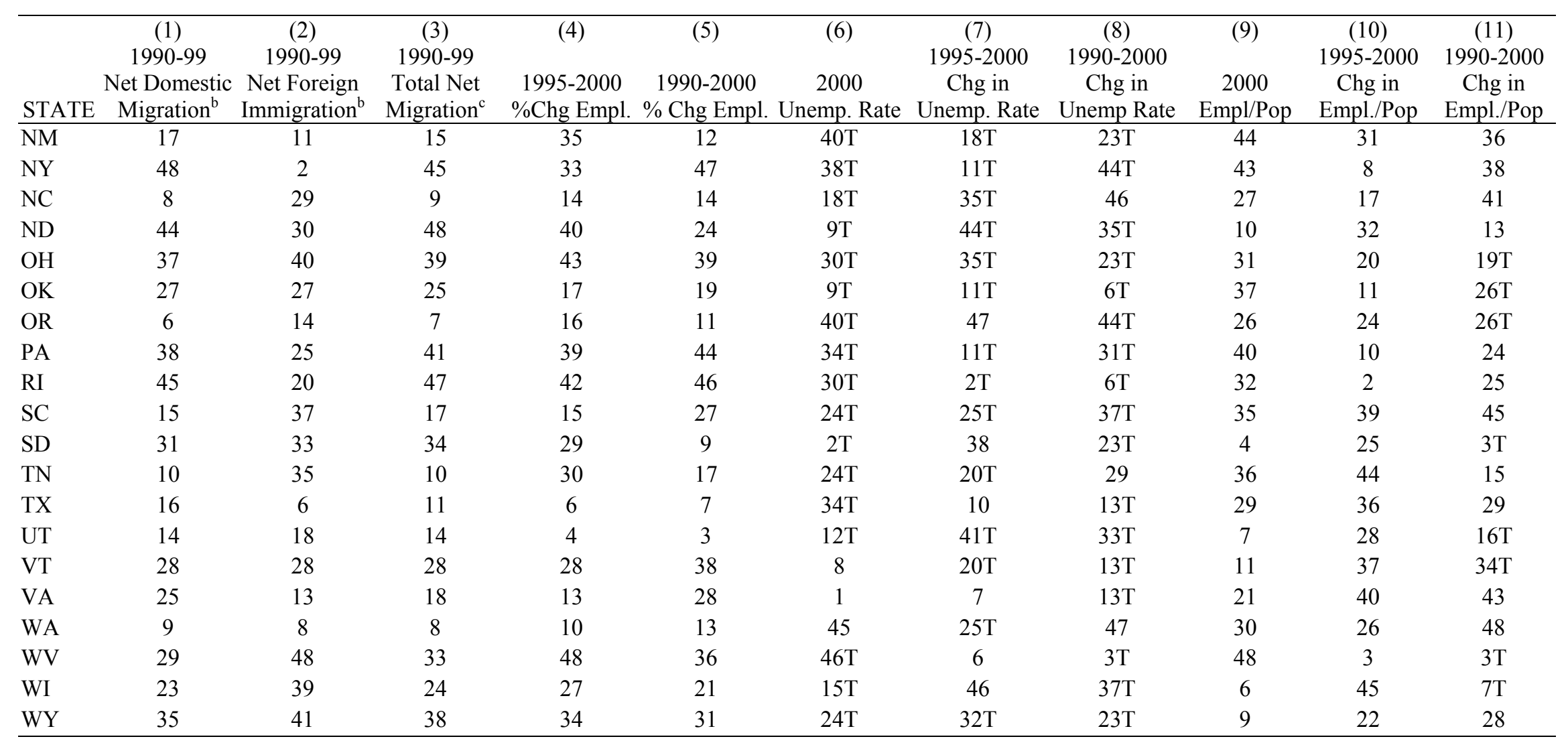

The rankings for the 48 contiguous states from most favorable to least favorable. The source for the migration data in columns (1)-(3) is the U.S. Census Bureau, 2001. The source for the employment and unemployment data is the Bureau of Labor Statistics, 2001.

b. Net 1990-1999 domestic or foreign migration as a share of 1990 population.

c. The ranking for the sum of net domestic and net foreign migration as a share of 1990 population. 


\section{TABLE 2}

Ranking of State Wage and Income Measures ${ }^{\mathrm{a}}$

\begin{tabular}{|c|c|c|c|c|c|c|c|c|c|}
\hline & \multicolumn{9}{|c|}{ (T denotes tie) } \\
\hline & (1) & $\begin{array}{c}(2) \\
1995-1999\end{array}$ & $\begin{array}{c}(3) \\
1990-1999\end{array}$ & (4) & $(5)$ & (6) & (7) & (8) & (9) \\
\hline State & $\begin{array}{c}1999 \\
\text { Per Capita } \\
\text { Income }\end{array}$ & $\begin{array}{c}\% \text { Chg in } \\
\text { Per Capita } \\
\text { Income }\end{array}$ & $\begin{array}{c}\% \text { Chg in } \\
\text { Per Capita } \\
\text { Income }\end{array}$ & $\begin{array}{c}1999 \\
\text { Annual Wage }\end{array}$ & $\begin{array}{c}1995-1999 \\
\text { \%Chg in } \\
\text { Annual Wage }\end{array}$ & $\begin{array}{c}\text { 1990-1999 } \\
\text { \%Chg in } \\
\text { Annual Wage }\end{array}$ & $\begin{array}{c}1999 \\
\text { PovertyRate }\end{array}$ & $\begin{array}{c}1995-1999 \\
\% \text { Chg in } \\
\text { Poverty Rate }\end{array}$ & $\begin{array}{c}\text { 1990-1999 } \\
\text { \%Chg in } \\
\text { Poverty Rate }\end{array}$ \\
\hline $\mathrm{AL}$ & 40 & 46 & 34 & 31 & 42 & 38 & 43 & 4 & 12 \\
\hline $\mathrm{AZ}$ & 33 & 17 & 30 & 22 & 12 & 16 & $28 \mathrm{~T}$ & 8 & 24 \\
\hline AR & 44 & 33 & 8 & 44 & 23 & 27 & 41 & 33 & 7 \\
\hline $\mathrm{CA}$ & 13 & 16 & 48 & 5 & 7 & 20 & 38 & 12 & 35 \\
\hline $\mathrm{CO}$ & 6 & 2 & 1 & 11 & 2 & 3 & 11 & 31 & 4 \\
\hline $\mathrm{CT}$ & 1 & 9 & 26 & 1 & 6 & 4 & 3 & 17 & 42 \\
\hline $\mathrm{DE}$ & 11 & 24 & 42 & 9 & 15 & 22 & 19 & 35 & 48 \\
\hline FL & 18 & 40 & 47 & 28 & 37 & 40 & 32 & 9 & 22 \\
\hline GA & 20 & 10 & 5 & 16 & 4 & 5 & 35 & 41 & 15 \\
\hline ID & 43 & 47 & 38 & 40 & 44 & 34 & 39 & 28 & 28 \\
\hline IL & 7 & 21 & 17 & 7 & 13 & 14 & $17 \mathrm{~T}$ & 19 & 13 \\
\hline IN & 28 & 34 & 21 & 23 & 29 & 30 & 2 & 13 & 2 \\
\hline IA & 31 & 26 & 25 & 39 & 24 & 25 & 6 & 5 & 16 \\
\hline $\mathrm{KS}$ & 25 & 12 & 24 & 30 & 20 & 31 & 31 & 45 & 45 \\
\hline KY & 39 & 27 & 15 & 32 & 25 & 35 & 30 & 18 & 5 \\
\hline LA & 42 & 45 & 14 & 36 & 45 & 45 & 47 & 32 & 11 \\
\hline $\mathrm{ME}$ & 35 & 20 & 46 & 37 & 35 & 43 & 20 & 29 & 19 \\
\hline $\mathrm{MD}$ & 5 & 29 & 45 & 10 & 18 & 23 & 5 & 14 & 18 \\
\hline MA & $2 \mathrm{~T}$ & 3 & 9 & 4 & 3 & 2 & $25 \mathrm{~T}$ & 40 & 41 \\
\hline MI & 17 & 43 & 23 & 8 & 32 & 19 & $15 \mathrm{~T}$ & 20 & 9 \\
\hline $\mathrm{MN}$ & 10 & 5 & 6 & 12 & 8 & 9 & 4 & 24 & 8 \\
\hline MS & 48 & 31 & 2 & 45 & 39 & 33 & 46 & 2 & 1 \\
\hline MO & 27 & 35 & 20 & 24 & 33 & 32 & $23 \mathrm{~T}$ & 47 & 23 \\
\hline MT & 45 & 41 & 43 & 48 & 46 & 44 & 44 & 38 & 30 \\
\hline $\mathrm{NE}$ & 22 & 18 & 19 & 34 & 22 & 21 & 21 & 44 & 38 \\
\hline NV & 9 & 32 & 16 & 17 & 34 & 26 & 22 & 37 & 44 \\
\hline $\mathrm{NH}$ & 8 & 7 & 13 & 18 & 10 & 13 & $7 \mathrm{~T}$ & 48 & 43 \\
\hline
\end{tabular}




\begin{tabular}{|c|c|c|c|c|c|c|c|c|c|}
\hline & (1) & $\begin{array}{c}(2) \\
1995-1999\end{array}$ & $\begin{array}{c}(3) \\
1990-1999\end{array}$ & (4) & (5) & (6) & (7) & (8) & (9) \\
\hline State & $\begin{array}{c}1999 \\
\text { Per Capita } \\
\text { Income }\end{array}$ & $\begin{array}{l}\text { \%Chg in } \\
\text { Per Capita } \\
\text { Income }\end{array}$ & $\begin{array}{l}\% \text { Chg in } \\
\text { Per Capita } \\
\text { Income }\end{array}$ & $\begin{array}{c}1999 \\
\text { Annual Wage }\end{array}$ & $\begin{array}{c}\text { 1995-1999 } \\
\text { \%Chg in } \\
\text { Annual Wage }\end{array}$ & $\begin{array}{c}\text { 1990-1999 } \\
\text { \%Chg in } \\
\text { Annual Wage }\end{array}$ & $\begin{array}{c}1999 \\
\text { PovertyRate }\end{array}$ & $\begin{array}{c}\text { 1995-1999 } \\
\text { \%Chg in } \\
\text { Poverty Rate }\end{array}$ & $\begin{array}{c}\text { 1990-1999 } \\
\text { \%Chg in } \\
\text { Poverty Rate }\end{array}$ \\
\hline $\mathrm{NJ}$ & $2 \mathrm{~T}$ & 22 & 40 & 3 & 17 & 12 & 9 & 34 & 26 \\
\hline NM & 46 & 48 & 31 & 38 & 43 & 37 & 48 & 6 & 34 \\
\hline NY & 4 & 13 & 33 & 2 & 11 & 8 & 40 & 21 & 33 \\
\hline $\mathrm{NC}$ & 29 & 38 & 18 & 26 & 14 & 7 & 37 & 42 & 36 \\
\hline ND & 37 & 15 & 27 & 46 & 40 & 41 & 36 & 43 & 32 \\
\hline $\mathrm{OH}$ & 21 & 37 & 36 & 19 & 36 & 39 & $28 \mathrm{~T}$ & 39 & 37 \\
\hline OK & 41 & 39 & 44 & 43 & 47 & 47 & 34 & 7 & 17 \\
\hline OR & 23 & 36 & 22 & 21 & 16 & 6 & 33 & 46 & 47 \\
\hline PA & 16 & 30 & 37 & 15 & 30 & 28 & 13 & 15 & 25 \\
\hline RI & 15 & 14 & 32 & 20 & 26 & 29 & $17 \mathrm{~T}$ & 26 & 46 \\
\hline $\mathrm{SC}$ & 36 & 28 & 28 & 35 & 38 & 36 & $25 \mathrm{~T}$ & 1 & 10 \\
\hline SD & 34 & 4 & 4 & 47 & 21 & 15 & $7 \mathrm{~T}$ & 3 & 3 \\
\hline $\mathrm{TN}$ & 32 & 42 & 10 & 27 & 28 & 17 & 27 & 10 & 6 \\
\hline $\mathrm{TX}$ & 24 & 6 & 7 & 14 & 5 & 10 & 42 & 22 & 29 \\
\hline UT & 38 & 8 & 3 & 29 & 27 & 24 & 1 & 16 & 20 \\
\hline VT & 30 & 25 & 41 & 33 & 31 & 42 & $15 \mathrm{~T}$ & 27 & 27 \\
\hline VA & 14 & 19 & 35 & 13 & 9 & 11 & 10 & 23 & 14 \\
\hline WA & 12 & 1 & 11 & 6 & 1 & 1 & 14 & 11 & 39 \\
\hline WV & 47 & 44 & 39 & 42 & 48 & 48 & 45 & 25 & 21 \\
\hline WI & 19 & 23 & 12 & 25 & 19 & 18 & 12 & 36 & 31 \\
\hline WY & 26 & 11 & 29 & 41 & 41 & 46 & $23 \mathrm{~T}$ & 30 & 40 \\
\hline
\end{tabular}

a. The rankings for the 48 contiguous states from most favorable to least favorable. The sources for the wage and income data are the U.S. Bureau of Economic Analysis, "State Personal Income, 1929-99." CD-ROM, November 2000. The poverty data are from the U.S. Census Bureau, 2001. 
The migration patterns are generally as expected. A swath of old "rust-belt" states running from southern New England through the Great Lakes region (i.e., Massachusetts to Illinois) have among the lowest net domestic migration rates. Of these ten states, nine are ranked in the bottom twelve. (The exception is Indiana.) Since these nine states have per capita incomes in the upper half of the nation, amenities may play an important role in retaining population. Likewise, the sunbelt states of Arizona, Florida, Georgia, and Nevada rank near the top in terms of domestic migration. Along with the mountain states of Colorado and Idaho, it appears that favorable climate/topography influenced these states' net migration. ${ }^{12}$ Although amenity attributes such as climate and topography are not likely to have changed much during this period, the utility attachment to them may have because of life-cycle considerations and increased income in the United States (Mueser and Graves 1995). In addition, endogenous amenity components such as pollution and congestion may have played a role. Yet even as amenities appear to be a key causal factor for these patterns, the long-term influence of demand factors such as the secular decline in manufacturing also may underlie some of the relative northern state declines.

An apparent exception to the positive natural amenity-net domestic migration relationship is California, which ranks forty-seventh in net domestic migration. One potential reason for California's poor showing in the 1990s was the effects of the 1990-1991 recession that hit particularly hard on the coasts. Another is that the largest cities in California may have grown beyond their optimal size, with continued population growth fueled by immigration, not domestic migration. Even so, with California's concentration of so-called "new economy" industries, we might have predicted positive utility differentials. Yet generally, states with concentrations of new economy industries registered ambiguous performances. For example, along with California's forty-seventh ranking, Massachusetts ranked forty-first, Texas sixteenth, and Washington ninth. ${ }^{13}$

Densely populated states also fared relatively poorly (e.g., New Jersey, New York, and Illinois). Taken together with the new economy evidence, this suggests that static or dynamic externalities did not sufficiently raise the productivity/wages of workers to offset other factors that led to significant out-migration (see Glaeser et al. 1992). This supports Hansen's (2001) contention that dynamic externalities may not be as strong as some observers have speculated.

One problem with only examining net migration is that it does not tell us why people are moving across regions. For example, even as Arizona's or Florida's strong net migration is consistent with favorable household amenities such as climate, it also may reflect low taxes or business-friendly regulations. To obtain a better understanding of the sources of migration flows, we examine other labor market indicators (columns (4)-(11)).

With the possible exception of income, the most widely used measure of regional labor market success is job growth. Thus, column (4) presents the relative rankings for 1995-2000

\footnotetext{
${ }^{12}$ In an examination of population and employment change in 86 rural western mountain counties from 1985-1994, Booth (1999) finds that amenities such as ski areas and national parks contribute to growth, not the traditional location-dependent industries (e.g., resource extractive industry).

${ }^{13}$ Because the "new economy" took off around 1995, focusing on the entire decade may be misleading. Yet, even examining the peak of the new economy in 1999 does not change the mixed picture. In terms of net domestic migration (not shown), California ranked thirty-fifth, Massachusetts thirty-second, Texas sixteenth, and Washington eighteenth.
} 
nonfarm job growth, and column (5) contains analogous rankings for 1990-2000. A comparison of columns (4) and (5) reveals some significant differences between a state's five-year job growth ranking and its ten-year ranking. ${ }^{14}$ For example, Arkansas ranked fifteenth over the entire decade but thirty-eighth in the latter half of the decade. Reflecting the severity of the defense downsizing in the early 1990s, California's job growth ranked thirty-seventh over the entire decade but ninth in the latter half of the decade. Yet the ten-year rankings more likely represent long-term trends. The ten-year job growth rankings also are highly correlated with the overall migration ranking, illustrating the important role that net migration may play in determining long-term job-growth differentials (Blanchard and Katz 1992). ${ }^{15}$

Consistent with the migration patterns, job growth in the New England and Mid-Atlantic Census Regions lagged those in the Mountain Region. Yet, states in the West North Central and West South Central Regions ranked higher in employment growth than in domestic migration. This suggests other relative supply sources of employment growth in these states.

One source of employment growth is a reduction in unemployment. As indicated by our model though, high unemployment is not necessarily reflective of weak labor demand (i.e., low degree of economic development) relative to other areas. A high unemployment rate may result from higher levels of amenities (Partridge and Rickman 1997a) or higher wage rates, because they serve as compensating differentials for the greater probability of unemployment. Thus, unemployment need not decrease in response to job growth if amenities or wage rates increase. Even if amenities or wage rates do not change, the region may be at its "equilibrium" unemployment rate, such that new jobs are primarily filled by in-migrants. To examine these possibilities, column (6) displays the ranking of the 2000 state unemployment rates, while columns (7) and (8) respectively report the state rankings for the 1995-2000 and 1990-2000 change in unemployment rates.

Column (6) shows that the overall 2000 unemployment rate is not a strong indicator of recent job growth (Bartik 1993). For example, Connecticut had the second lowest unemployment rate in 2000, even as job growth was the lowest in the nation during the 1990s. To be sure, because of the high college graduate shares in their labor force, New England states in general have lower unemployment rates than would be suggested by their job growth ranking (Partridge and Rickman 1997a). Conversely, having the fourth highest unemployment rate is not consistent with Washington's strong job-growth performance. In fact, the Spearman Rank Correlation $\left(r_{S}\right)$ between 1990-2000 job growth and the 2000 unemployment rate equals -0.048 . This near zero correlation is consistent with the notion that each state has its own relative long-run equilibrium unemployment rate.

Perhaps surprisingly, the change in the unemployment rate ranking in the 1990s is even more negatively correlated with the 1990-2000 job growth ranking $\left(r_{S}=-0.224\right)$. In some cases, such as California, Delaware, and Maryland, changes in the unemployment rate correspond closely to employment changes. However in the New England states, Nevada, and West Virginia, the relationship is the exact opposite of what would be expected. The divergence in unemployment from employment may somewhat result from domestic migration patterns: lower net in-

\footnotetext{
${ }^{14}$ The Spearman rank correlation coefficient for 1995-2000 and 1990-2000 job growth is .602.

${ }^{15}$ The Spearman rank correlation between net domestic migration and 1990-2000 job growth rates is .827 .
} 
migration in New England and West Virginia and greater migration and immigration into Nevada. $^{16}$

Columns (9)-(11) repeat the above using the employment-population ratio in place of the unemployment rate. Although the employment-population ratio is infrequently used by economists and almost never mentioned in public discourse, it contains useful information about economic development. As noted by Murphy and Topel (1997), it can be much more informative than the unemployment rate because many of the nonemployed have a closer relationship to the labor market than suggested by official labor-force definitions. In fact, Partridge (2001) finds that about one-third of newly created jobs at the state level are taken by people who were not officially part of the labor force.

The state rankings of employment-population ratios in year 2000 are correlated with the unemployment rate rankings $\left(r_{S}=.674\right) .{ }^{17}$ Yet, there are some key differences. For example, both Massachusetts and Virginia had a slacker labor market than their unemployment rate would suggest, while the Minnesota and Wyoming employment-population rankings were more favorable than their unemployment-rate rankings. The ranking of the change in the employmentpopulation ratio, however, is not necessarily synonymous with the employment growth ranking. For example, Connecticut and West Virginia had very sluggish job growth during the 1990s. In the case of Connecticut, it was one of only four states whose employment-population ratio declined over the decade, suggesting that the original residents bore a severe price for its relatively sluggish job growth. Conversely, West Virginia's employment-population ratio showed one of the steepest increases during the 1990s, suggesting that many original residents benefited from their job growth. ${ }^{18}$ In general, states in the North Central Census Region moved up in the employment-population ratio rankings compared to their rankings of migration and job growth. At the other extreme, despite Nevada's stellar employment growth in the 1990s, their original residents may not have been among the main beneficiaries as their employment population-ratio declined (and their unemployment rate only slightly improved). This was also, on average, somewhat true for the Mountain states, Oregon, and Washington.

Per capita income is a widely used measure that is commonly perceived as reflecting the level of economic development success. In fact, if full employment and the absence of amenities (and public-good provision) were assumed in our model, total utility would equate with real income. Thus, Table 2 presents an analogous set of rankings for various measures of income. Column (1) shows the ranking for 1999 per capita income, while columns (2) and (3) respectively contain the relative ranking for the 1995-1999 and 1990-1999 percent change in per capita income. ${ }^{19}$

\footnotetext{
${ }^{16}$ The Spearman rank correlation coefficient for domestic migration and the change in unemployment for all states equals -0.106 , while the comparable figure for immigration is -0.184 .

${ }^{17}$ The correlation is lower between the rankings of the 1990-2000 changes in the employment-population ratios and unemployment rates $\left(r_{S}=.277\right)$.

${ }^{18}$ Changes in the employment-population ratio are a clear signal of the success of original residents only when migrants have about the same employment-population ratios as the original residents. Fortunately, Bartik (1993) shows that this is generally the case.

${ }^{19}$ Per capita income for 1999 was used instead of 2000 per capita income because the 2000 estimates by the Bureau of Economic Analysis were based on the 2000 Census; but when this was written, per capita income figures before
} 
Connecticut, Massachusetts, New Jersey, and New York have high per capita income rankings, which are suggestive of productive economies and economic well being. Yet, given that net migration is the avenue through which households are assumed to reveal their preferences in the model, the negative net migration from these states implies a lower quality of life. Hence, the high per capita incomes may in part reflect congestion, environmental, or weather-related disamenities. ${ }^{20}$ These states also possess relatively higher rates of immigration, which may be increasing labor market competition and/or causing cities in these states to grow beyond their optimal size. To be sure, California ranks fairly high in per capita income, yet it experienced significant domestic out-migration despite possessing favorable natural amenities. Correspondingly, the low wages combined with high net migration rates in some Mountain states may reflect high natural-amenity levels. The low per capita incomes of Arkansas, Louisiana, Mississippi, and West Virginia are consistent with their very low employment-population ratios. $^{21}$

Regarding the percent change in per capita income, there is no clear pattern of income convergence across states. The change in per capita income is most positively correlated with wage rate growth $\left(r_{S}=.485\right)$. This is followed by less correlation with employment growth $\left(r_{S}=.433\right)$, the change in the employment-to-population ratio $\left(r_{S}=.302\right)$, and domestic migration $\left(r_{S}=.264\right)$. Yet the positive association between net migration and wage rates suggests that migration flows were not just labor-supply responses to amenities but also reflect responses to labor demand shifts. The change in per capita income is slightly negatively related to foreign immigration $\left(r_{S}=-0.089\right)$.

Because per capita income contains components that are not directly related to the labor market, such as earnings from interest and dividends, and reflects employment-population ratios, we present analogous information for wages using annual earnings per worker. As seen in column (4), average wages in 1999 were highest in Connecticut, Massachusetts, New Jersey, and New York, consistent with the per capita income rankings $\left(r_{S}=.893\right)$. Perhaps more importantly, high-wage states also experienced rapid wage growth over the $1990 \mathrm{~s}\left(r_{S}=.721\right)$. Even as the creation of high-wage jobs contributed to improved economic well being, outmigration from these states suggests that they exceeded their optimal sizes, or there may have been mismatches of jobs and skills at the lower end of their wage distributions. Despite favorable amenities, Washington and Colorado experienced strong wage gains, which suggests that their amenities may have contributed to the creation of high-paying jobs. At the other end of the spectrum, with wage levels, wage growth, and domestic migration among the lowest in the

2000 had not been benchmarked to the 2000 Census. Thus, the 2000 per capita incomes are not comparable to earlier years.

${ }^{20}$ The Spearman rank correlation coefficient between 1999 per capita income and 1990-1999 domestic migration is -.271 .

${ }^{21}$ Rather than using net migration, changes in employment, changes in per capita income, etc., Roback (1982) identifies changes in firm and household amenities through changes in wages and housing/land prices. Although the housing market is also conceptually affected by changes in economic conditions, using housing prices to help identify the causal mechanism requires detailed information on housing prices as well as the quality of the housing stock. In addition, with housing prices having a strong local orientation, measures of welfare used in this paper appear more applicable to state policymakers. 
country, Louisiana, Maine, North Dakota, West Virginia, and Wyoming appear to have a need for economic development in terms of creating high-wage jobs.

The case of Montana illustrates the complex interactions in the underlying economic model. In 1999, Montana had the lowest wages in the nation, which followed a decade of very sluggish wage growth. The wage performance suggests very low productivity levels. Moreover, the relatively strong rise in the employment-population ratio suggests that people entered the labor market to make ends meet (or a liquidity constraint), akin to an added worker effect due to unemployment. Yet favorable net migration patterns (especially in the early 1990s) suggest an above-average quality of life, at least for nonlabor-force participants. Other interesting cases include the "new-economy" states such as California, Massachusetts, Texas, and Washington. For the most part, these states experienced strong wage growth in the 1990s, perhaps associated with high productivity growth resulting from technological innovations (Riddel and Schwer 2003). Yet their wage performance did not necessarily translate into favorable net migration flows.

A potential problem with analyzing average income or wages is that it ignores issues related to income distribution such as reducing poverty. Given their lower willingness to migrate, utility differentials among low-skilled labor likely persist across regions for sufficiently long periods so as to be a policy concern. That is, domestic migration may be less likely to be reflective of lowskilled labor utility differentials than are relative poverty rates, suggesting that policies designed to eradicate poverty may need to be "place" specific, not just person specific. To examine the connection between poverty and other regional economic indicators, column (7) presents the states' rankings for the 1999 poverty rate, while columns (8) and (9) illustrate the respective rankings in terms of the 1995-1999 and 1990-1999 change in poverty rates.

Column (7) shows instances where high-income states such as Connecticut and Minnesota had low poverty rates, while low-income states such as Louisiana and New Mexico had high poverty rates. Yet New York had the fortieth highest poverty rate despite high average income, while Utah had the lowest poverty rate despite having a low average income. In fact, the rank correlation coefficient between per capita income and the poverty level is .556 (with $r_{S}=.405$ for poverty with wage rates). Poverty rates are more correlated with unemployment rates $\left(r_{S}=.657\right)$ and employment-to-population ratios $\left(r_{S}=.649\right)$.

Regarding changes in the poverty rankings, several states that had among the highest poverty rates were among those with the most improvement. For example, the poverty rate of Mississippi in 1999 placed it at forty-sixth, while Mississippi was first in poverty reduction during the 1990s. This was the general pattern in the East South Central Census Region. As expected, reflecting sluggish migration patterns among low-income households, there was low correlation between the change in poverty rates and net migration $\left(r_{s}=.09\right)$.

The change in poverty rate is most correlated with an increasing employment-to-population ratio $\left(r_{S}=.467\right)$, followed by a reduction in the unemployment rate $\left(r_{S}=.291\right)$. The change in the wage growth ranking was negatively associated with the change in the poverty ranking $\left(r_{S}=-0.121\right)$, indicating that average wage rates have more of an influence on the well being of those above the poverty level. As an example, it is somewhat surprising that Massachusetts and 
Oregon had higher poverty rates at the end of the 1990s than at the beginning since both states had relatively rapid wage growth (and Oregon had fairly strong job growth). South Dakota, on the other hand, experienced rapid job growth compared to the nation and a relative reduction in poverty. This can be explained as variations in employment conditions most affecting those at the bottom of the income distribution. Hence, policies that reduce unemployment and increase employment-to-population ratios may be most effective in reducing poverty (Bartik 2001).

\section{SUMMARY AND CONCLUSION}

In this paper we argue that economic development in a region should be equated with utility of its current residents. Absent direct utility measures though, the theoretical framework and analysis of the data suggest that there is no single measure of progress in economic development. The correct indicator of economic development, or combination of indicators, depends upon the characteristics of the region.

For high-skilled mobile workers, utility differentials are likely reflected in interregional domestic migration. Whether it is due to higher quality of life or better economic opportunities, higher utility in the region induces domestic in-migration. Yet for migration apparently related to amenities, inverse relationships between domestic migration and per capita income/wage rates were observed for many states. This relationship indicates that average wages and income are incomplete measures of economic development for these states.

In addition, because they are less mobile, utility differentials are less likely to induce migration of domestic low-skilled workers. Low-skilled regional utility differentials are more likely reflected in poverty rate differentials. Changes in poverty rates were found to be more associated with changes in employment conditions than with changes in average wage rates or per capita income, again showing that income measures provide an incomplete picture of economic development.

Despite the complexities involved in measuring economic development success, there are some states that clearly seemed to have been successful. Despite cold climates, Minnesota and to some extent South Dakota fared well in most indicators: improved job growth and employment-to-population ratios, low unemployment rates, above-average income growth, and greater-than-average reductions in poverty. Minnesota even had positive domestic in-migration and international immigration rates that were above the median. Colorado and Georgia also rank near the top in improved performance in all categories. Given strong employment and per capita income growth, the fastest wage growth, and among the highest rate of domestic in-migration, Washington appeared successful at the high-skilled labor end. Yet they ranked near the bottom in improving the unemployment rate, the employment-to-population ratio, and the poverty rate. On the other hand, California, North Dakota, West Virginia, and Wyoming fared poorly in most categories.

What underlies the difference in outcomes is not easy to answer. For example, on the surface, the Dakotas seem to have much in common, even though South Dakota has outperformed its northern neighbor. Likewise, relatively successful Minnesota has a reputation of activist government intervention, which is the opposite of South Dakota. Freeman (1998) presents an 
argument that may explain this apparent contraction. He contends that many government policies alter basic property rights. For example, a strong environmental law shifts environmental property rights away from polluters. Hence, the Coase theorem implies that with side payments among economic actors, these types of policies should still yield efficient outcomes. Illustrating the mixed outcomes, Brown, Hayes, and Taylor (2003) finds that government fiscal policies have an ambiguous impact on economic activity, although on balance they tend to reduce economic growth. What then needs to be determined is why some areas like Minnesota were exceptions to this finding.

The existence of regional differences in amenities further complicates assessment of outcomes where many states with natural amenities fare well in terms of net migration. Taken together, these different outcomes at the sub-national level support the argument of Richard Freeman (2000) that there is no single-peaked way to achieve economic success. We add that there is no single-peaked way to measure economic development success.

\section{REFERENCES}

Barro, R.J. and X. Sala-i-Martin, 1992. “Convergence,” Journal of Political Economy 100, 223251.

Bartik, T.J., 1993. "Who Benefits from Local Job Growth: Migrants or Original Residents," Regional Studies 27, 297-311.

, 1996. "The Effects of Metropolitan Job Growth on the Size Distribution of Family Income," Journal of Urban Economics 40, 150-178.

, 2001. Jobs for the Poor: Can Labor Demand Policies Help? New York: Russell Sage Foundation.

Beauregard, R.A., 1999. "The Employment Fulcrum: Evaluating Local Economic Performance," Economic Development Quarterly 13(1), 8-14.

Beeson, P.E. and R.W. Eberts, 1989. "Identifying Productivity and Amenity Effects in Interurban Wage Differentials," Review of Economics and Statistics 71, 443-452.

Blanchard, O.J. and L.F. Katz, 1992. "Regional Evolutions," Brookings Papers on Economic Activity 1, 1-75.

Blanchflower, D.G. and A.J. Oswald, 1994. The Wage Curve. Cambridge, MA: MIT Press.

Booth, D.E., 1999. "Spatial Patterns in the Economic Development of the Mountain West," Growth and Change 30(3), 384-405.

Bound, J. and H. Holzer, 2000. "Demand Shifts, Population Adjustments, and Labor Market Outcomes in the 1980s," Journal of Labor Economics 18, 20-54.

Brown, S.P.A., K.J. Hayes, and L.L. Taylor, 2003. "State and Local Policy: Factor Markets and Regional Growth," The Review of Regional Studies 33(1), 40-60.

Courant, P.N., 1994. "How Would You Know a Good Economic Development Policy if You Tripped Over One? Hint: Don’t Just Count Jobs,” National Tax Journal 47, 863-881. 
Dalenberg, D. and M.D. Partridge, 1997. "Public Infrastructure and Wages: Public Capital's Role as a Productive Input and Household Amenity," Land Economics 73, 268-284.

Douglas, S., 1997. "Estimating Relative Standard of Living in the United States Using CrossMigration Data," Journal of Regional Science 37(3), 411-436.

Freeman, R.B., 1998. "War of the Models: Which Labour Market Institutions for the 21st Century?" Labour Economics 5, 1-24. , 2000. “The U.S. Economic Model at Y2K: Lodestar for Advanced Capitalism?" NBER Working Paper \#7757, June. , 2001. "Rising Tide Lifts...?" National Bureau of Economic Research Working Paper \#8155, March.

Frey, W.H., 1995. "Immigration and Internal Migration 'Flight' from U.S. Metro Areas: .Toward a New Demographic Balkanisation," Urban Studies 32, 733-757.

Glaeser, E.L., J. Kolko, and A. Saiz, 2000. “Consumer City,” Harvard Institute of Economic Research Discussion Paper 1901.

Glaeser, E.L., H. Kallal, J. Sheinkman, and A. Shleifer, 1992. “Growth in Cities,” Journal of Political Economy 100, 1126-1152.

Glaeser, E.L., J.A. Sheinkman, and A. Shleifer, 1995. "Economic Growth in a Cross-Section of Cities," Journal of Monetary Economics 36, 117-143.

Greenwood, M.J. and G.L. Hunt, 1989. "Jobs versus Amenities in the Analysis of Metropolitan Migration," Journal of Urban Economics 25, 1-16.

Gyourko J. and J. Tracy, 1989. "The Importance of Local Fiscal Conditions in Analyzing Local Labor Markets," Journal of Political Economy 97, 1208-1231.

Hansen, N., 2001. "Are Very Large Cities Successful? Searching for Dynamic Externalities versus Evidence from Population Movements," International Regional Science Review 24, 344-359.

Harris, J.R. and M.F. Todaro, 1970. "Migration, Unemployment, and Development: A TwoSector Analysis," American Economic Review 60, 126-142.

Herzog, H.W. and A.M. Schlottmann, 1993. "Valuing Amenities and Disamenities of Urban Scale: Can Bigger be Better?” Journal of Regional Science 33, 145-165.

Jacobs, J., 1969. The Economies of Cities. New York: Random House.

Levernier, W., M.D. Partridge, and D.S. Rickman, 2000. "The Causes of Regional Variation in U.S. Poverty: A Cross-County Analysis," Journal of Regional Science 40(3), 473-497.

Marston, S., 1985. "Two Views of the Geographic Distribution of Unemployment," Quarterly Journal of Economics 100, 57-79.

Mathur, V.K. and S.H. Stein, 1993. "The Role of Amenities in a General Equilibrium Model of Regional Migration and Growth," Southern Economic Journal 59, 394-409. 
McGregor, P.G., J.K. Swales, and Y.P. Yin, 1995. "Migration Equilibria in Regional Economies: A Multi-Period CGE Analysis of an Improvement in Local Amenities," in J.C. van den Bergh, P. Nijkamp, and P. Rietveld (eds.), Recent Advances in Spatial Equilibrium Modeling. New York: Springer.

Moomaw, R.L., 1981. "Productivity and City Size," Quarterly Journal of Economics 96, 675688.

, 1983. "Is Population Scale a Worthless Surrogate for Business Agglomeration Economies," Regional Science and Urban Economics 13, 525-545.

Morgan, W., J. Mutti, and D. Rickman, 1996. "Tax Exporting, Regional Economic Growth, and Welfare," Journal of Urban Economics 39, 131-159.

Mueser, P.R. and P.E. Graves, 1995. "Explaining the Role of Economic Opportunity and Amenities in Explaining Population Redistribution," Journal of Urban Economics 37, 176200.

Murphy, K.M. and R. Tope, 1997. "Unemployment and Nonemployment," American Economic Review 87, 295-300.

Partridge, M.D., 2001. "Exploring the Canadian-U.S. Unemployment and Nonemployment Rate Gaps: Are There Lessons for Both Countries?” Journal of Regional Science 41, 701-734.

and D.S. Rickman, 1997a. "The Dispersion of U.S. State Unemployment Rates: The Role of Market and Non-Market Equilibrium Factors," Regional Studies 31, 593-606.

, 1997b. "Has the Wage Curve Nullified the Harris-Todaro Model?: Further U.S.

Evidence," Economics Letters 54, 277-282.

Porter, E., 2001. "Number of Hispanics Ballooned in 90's, Set to Pass Total of Blacks," Wall Street Journal, March 8, A24.

Rauch, J.E., 1993. "Productivity Gains from Geographic Concentration of Human Capital: Evidence from the Cities," Journal of Urban Economics 34, 380-400.

Riddel, M. and R.K. Schwer, 2003. "Regional Innovative Capacity with Endogenous Employment: Empirical Evidence from the U.S.," The Review of Regional Studies 33(1), 7384.

Roback, J., 1982. "Wages, Rents, and the Quality of Life," Journal of Political Economy 90, 1257-1278.

, 1988. "Wages, Rents, and Amenities: Differences Among Workers and Regions," Economic Inquiry 26, 23-41.

Romer, P., 1986. "Increasing Returns and Long-Run Growth," Journal of Political Economy 94, 1002-1037.

Rosen, S., 1979 "Wage-Based Indexes of Urban Quality of Life," in P.Mieszkowski and M. Straszheim (eds.), Current Issues in Urban Economics. Baltimore: John-Hopkins Univ. Press.

Southern Growth Policies Board, 2001. Available at http://www.southern.org. 
Treyz, G.I., D.S. Rickman, G.L. Hunt, and M.J. Greenwood, 1993. “The Dynamics of U.S. Internal Migration," Review of Economics and Statistics 75, 209-214.

U.S. Bureau of Labor Statistics, 2001. Available at http://stats.bls.gov/datahome.htm.

U.S. Economic Development Administration (EDA), 2001. Available at http://www.doc.gov.eda/.

Wolman, H. and D. Spitzley, 1996. “The Politics of Local Economic Development," Economic Development Quarterly 10(2), 115-150. 